\title{
Corporate governance and business ethics
}

\author{
Douglas R McKay MD MBA FRCSC ${ }^{1}$, Romy Nitsch MD MHSC(Ethics) FRCSC ${ }^{2}$, Daniel A Peters MD MBA FRCSC ${ }^{3}$
}

$\mathrm{T}$ he primary objective of a corporation is to increase shareholder value. Successful corporations must operate within society; to that end, they must maintain the values and norms of the society in which they operate. Volkswagen has been the unfortunate recipient of a great deal of press time lately. In case you missed the details, it recently came to light that Volkswagen knowingly deceived the United States Environmental Protection Agency (EPA) with respect to nitrous oxide $(\mathrm{NOx})$ engine emission for their TDI engines. The company programmed the vehicles to favourably behave differently during EPA testing. The engines actually exceeded emission test levels during every day use by roughly 40 fold. The number of affected vehicles is not small - approximately 11 million cars worldwide. While the old adage goes that there is no such thing as bad publicity, the company's publically traded market share losses topped €14 billion during the fallout, suggesting otherwise.

The scandal has fueled the ire of those who question the altruism and decry the intent of big business. The scandal has thrown the subject of business ethics back into the spotlight. The corporations or organizations surgeons typically navigate are hospitals and universities - institutions held to strong social standards of ethical accountability. However, hospitals are not the only organizations we interact with. We use the products of for-profit corporations and make decisions on behalf of our patients many times without them knowing a choice has been made. We have the good fortune of working with ethically strong corporate partners in a highly regulated industry, but Volkswagen has shown us it is both academically interesting and prudent in practice to understand the ethical tenets governing our corporate partners in patient treatment as they balance their efforts to advance medical research while increasing shareholder value.

\section{CORPORATE GOVERNANCE AND THE LAW}

At the end of the 20th century, public confidence in a corporation's ability to self-govern was low. A number of scandals had shaken the landscape and rattled investor confidence. Concerns about possible economic fallout prompted the United States House and Senate to enact the Public Company Accounting Reform and Investor Protection Act. This is better known as the Sarbanes-Oxely Act of 2002. Sarbanes-Oxely laid out legal obligations for publically traded and privately held corporations, with an aim to improving accountability. Canada followed suit with Bill C-198. It is identical in principle, albeit subtly varied in accountability and execution.

Oversight outlined in the act includes objective mandates such as auditor independence, enhanced disclosure and criminal fraud accountability, as well as subjective mandates like corporate responsibility. Sarbanes-Oxely and C-198 place the responsibility for steering corporate governance firmly on the board of directors and upper management. Corporations become legally obligated to follow a course of social compliance. Regulation falls on the Securities and Exchange Commission. It is easy to argue that some corporations make money through dealings in conflict with what is socially acceptable to the majority, but the theoretical purpose is the legal imposition of accountability.

\begin{abstract}
ETHICS VERSUS THE LAW
The law and ethics are not one and the same. Although the law can guide ethical behaviour through Sarbanes-Oxely by laying out a framework, ethicists are quick to point out that the law should be thought of as the bare minimum of an ethical framework. Complying with the law and behaving ethically are not necessarily synonymous. While Sarbanes-Oxely and C-198 specifically state that destroying evidence or fraudulent behaviour is illegal, they do not state that the series of questionable decisions that led to the fraud is as well. To guide the behaviour of the corporation, management must turn to the field of business ethics. In the case of Volkswagen, the execution of the deceptive computer program at the EPA emissions test laboratory is where the law was broken, the act of which carries punitive fines and penalties based on the retributions of crime and punishment. The work that preceded that breach and the culture of deception that brought it to fruition constitutes a slew of ethical violations according to social standards.
\end{abstract}

\section{NORMATIVE DIRECTIVES IN ETHICS}

Philosophical ethics has different fields of study. Normative ethics focuses on right and wrong. It is generally concerned with applying a framework of moral code on a decision. Descriptive ethics, on the other hand, looks at the understanding of an underlying moral belief. The field of business ethics is principally focused on steering a corporation toward doing right and away from doing wrong. It is principally normative. The field of business ethics attempts to guide corporations through ethically difficult decisions.

\section{BUSINESS ETHICS IN OVERVIEW}

The field of business ethics is not recently new but is relatively new. It arose in the 1970s and slowly gained acceptance as an academic discipline and practice through the decades that followed. Business ethics is temporal, that is to say that the guiding principles that arise through study may vary over time. While some principles remain concrete, social norms may vary over time, forcing once-acceptable practices into obsolescence. The environmental movement and the recognition that we are destroying our planet may have changed the public's perception of fossil fuel consumption. When the automobile industry first arose, burning more gas to glean more power was embraced, now efficiency and minimizing emissions is the more acceptable standard. While some might believe that it is intuitively obvious that a corporation should be ethically constrained to act within the norms of society, the pure advocates of unadulterated capitalism don't necessarily agree.

There are those who argue ethical constraints are unnecessary and harmful. They believe that the progress of a corporation is impeded through constraint and, as such, the advancement of the corporation toward its goals are restricted. The argument follows that society as a whole suffers as progress - medical, technical or otherwise - is stunted. While this view may seem extreme, the business literature suggests that is not entirely the case. In fact, in an international study in 2011 (1), only $30 \%$ to $80 \%$ of high management believed that a corporation had an obligation to do well by society in addition to making shareholder's more money.

${ }^{1}$ Division of Plastic Surgery, Department of Surgery; ${ }^{2}$ Department of Obstetrics $\mathcal{E}$ Gynecology, Queen's University, Kingston; ${ }^{3}$ Division of Plastic Surgery, Department of Surgery and Telfer School of Management, University of Ottawa, Ottawa, Ontario

Correspondence: Dr Douglas R McKay, Division of Plastic Surgery, Department of Surgery, Queen's University, Hotal Dieu Hospital, 166 Brock Street, Brock 3R, B3031, Kingston, Ontario K7L 5G2. Telephone 613-544-3400 ext 2494, fax 613-544-3709,

e-mail mckayd1@kgh.kari.net 
The areas of an organization potentially subject to ethical analysis are practically unlimited. Human resources, contract negotiations, new business development, accounting and finance, can all be subject to ethical analysis and constraint. What arises over time is a corporate culture that falls under the umbrella of the values of the corporation. The corporation begins to adhere to organization ethics but also can self-define an operating culture in alignment with society.

\section{CORPORATE SOCIAL RESPONSIBILITY}

Corporations began touting their ethical behaviour and integrity as a value add for consumers through the 1990s. Since that time, the term 'corporate social responsibility' (CSR) has gained a great deal of traction. CSR extends beyond legal compliance and, as a philosophy, suggests that corporations can give back to the societies in which they operate even if this return decreases profit. This idea has both is advocates and its detractors.

The detractors believe that this isn't the role of a business and that businesses should stick to what they know: profit. Expanding their focus away from the core business weakens their benefit to the economy and decreases their utility to society. Those who support CSR principally believe that operating with a social conscience aligns corporations with the values of its customers and increases long-term profits. This belief can arguably lead to a degree of cynicism with regard to the altruism of the motivation; if the focus is on profit then isn't CSR merely a tool for self-promotion and increased shareholder value?

\section{ALTRUISM AND HIDDEN ECONOMIC GAIN}

Take Volkswagen as an example. The low emissions diesel engine was touted as a win for the environment. Diesel engines consume less fuel and, if emissions comply with regulation, there is environmental advantage through their purchase and use. This advantage was not lost on Volkswagen and the cars were successfully marketed to consumers who valued this feature. The company benefited in reputation and in profit by embracing socially responsible values. Unfortunately, that reputation belied the truth. This is a classic example, in which the ethical culture of the corporation was at opposition to the CSR that it touted.

\section{SUMMARY}

The field of business ethics is an expanding field. There are many corporations who have worked diligently to integrate ethical analysis into defining their corporate culture with an aim to social responsibility and return. There is a legal framework to guide these decisions, but the law and ethics are not one and the same. The law represents the bare minimum as an ethical framework. As a consumer, it is important to distinguish between mandates and choices that forprofit organizations value.

\section{REFERENCE}

1. Milton Friedman Goes on Tour. A Survey of Attitudes to Business Turns Up Some Intriguing National Differences. The Economist, January 27, 2011. 